\title{
濃度応答法による気固系流動層吸着塔の因子決定 初期流動化において—十
}

\author{
西尾匡弘・影井清一郎・若尾法昭 \\ 横浜国立大学工学部 物質工学科 ${ }^{\dagger \dagger}$
}

\begin{abstract}
モレキュラーシーブ $5 \mathrm{~A}$ の破砕微粒子の流動層にヘリウムガスを流し，ある瞬間にトレ 一サとして $\mathrm{N}_{2}$ ガスを遥か下方で注入し流動層の入口と出口での濃度 - 時間曲線を記録す る. この実測曲線から雑音を除いて濃度 - 時間曲線を平滑化し，それに基づいて流動層内 のガス混合係数亡吸着平衡定数の両者を流動化初期までの段階で求めた.
\end{abstract}

\section{緒言}

古く Gilliland ら ${ }^{1)}$ は流動層内を流れるガスの混合係数 測定を濃度の周波数応答法により試みたが，定量的な結 果を得るに至らなかった. それ以後む気固系流動層内の ガス混合についていくつかの研究が行われ，それらの結 果を宮内ら ${ }^{4,5)}$ がまとめているが，その他の研究の多くは 気泡の挙動に関するものとなった，反応装置としての気 固系流動層を考えると, ガス相を均相と考えてのガス混 合係数が分かれば, 固定層反応器と同様な方法で流動層 反応器の出口での流体濃度や反応収率を求めることがで きよう. ての考えに基づいてGunn ら ${ }^{2)}$ は熱応答法によ り気固系流動層のガス混合係数を求めている.

我々は気固系流動層の吸着実験を濃度応答法で行った。 濃度一時間曲線には流動化が進むとともに雑音信号が含 まれるが，乙の雑音信号を除去し平滑化された濃度一時 間曲線から吸着平衡定数, ガス混合係数を固定層から初 期流動化にいたる範囲で求めることができたので以下に 報告する．

\section{1. 理 論}

一本の円管内に吸着粒子の流動層を形成させる．乙の 円管内に不活性ガスを流し，ある瞬間にトレーサとして の吸着性ガスを流動層の遥か下方でパルスとして注入す る. 流動層支持板の下方距離 $L_{1}$ (Fig. 1 (b) 参照 )でこの トレーサガスの濃度一時間曲線を測る。流動層の高さは $L$ であり，層上端面から距離 $L_{2}$ 上方で再びこのトレー サガスの応答曲線を測る。

空管部分のガス混合係数は流動層下部でも上部でも等 しいと仮定し，乙れを $D^{*}$ とする。 また，粒子は球形とす

\footnotetext{
† 1989年 3 月 10 日受理

†† $\mathbf{T} 240$ 横浜市保土谷区常盤台 156
}

る. 流動層部分のガス混合係数を $D_{\mathrm{ax}}$, ガス濃度を $C$, 粒子細孔内ガス相中の吸着質濃度を $c$, 粒子内有効拡散 係数を $D_{\mathrm{e}}$ とすればこの系の物質収支は

(i) 区間 $0<x<L_{1}$ の空管部分

$$
\begin{aligned}
& \frac{\partial C^{\prime}}{\partial t}=D^{*} \frac{\partial^{2} C^{\prime}}{\partial x^{2}}-u \frac{\partial C^{\prime}}{\partial x} \\
& C^{\prime}=0 \quad \text { at } t=0
\end{aligned}
$$

(ii) 区間 $L_{1}<x<L_{1}+L$ の流動層部分

$$
\begin{aligned}
& \varepsilon_{\mathrm{b}} \frac{\partial C}{\partial t}=\varepsilon_{\mathrm{b}} D_{\mathrm{ax}} \frac{\partial^{2} C}{\partial x^{2}}-u \frac{\partial C}{\partial x}-a D_{\mathrm{e}}\left(\frac{\partial c}{\partial r}\right)_{R} \\
& \varepsilon_{\mathrm{p}} \frac{\partial c}{\partial t}=D_{\mathrm{e}} \frac{1}{r^{2}} \frac{\partial}{\partial r}\left(r^{2} \frac{\partial c}{\partial r}\right)-\rho_{\mathrm{p}} \frac{\partial c_{\mathrm{ad}}}{\partial t} \\
& D_{\mathrm{e}} \frac{\partial c}{\partial r}=k_{\mathrm{f}}(C-c) \quad \text { at } \quad r=R \\
& C=c=c_{\mathrm{ad}}=0 \quad \text { at } t=0
\end{aligned}
$$

(iii) 区間 $x>L_{1}+L$ の空管部分

$$
\begin{array}{ll}
\frac{\partial C^{\prime}}{\partial t}=D^{*} \frac{\partial^{2} C^{\prime \prime}}{\partial x^{2}}-u \frac{\partial C^{\prime \prime}}{\partial x} & \\
C^{\prime \prime}=0 & \text { at } t=0
\end{array}
$$

境界条件として

$$
\begin{array}{lll}
C^{\prime}=C^{\mathrm{I}}(t) & \text { at } x=0 & (5) \\
C^{\prime}=C & \text { at } x=L_{1} & (5 \mathrm{a}) \\
D^{*} \frac{\partial C^{\prime}}{\partial x}=\varepsilon_{\mathrm{b}} D_{\mathrm{ax}} \frac{\partial C}{\partial x} & \text { at } x=L_{1} \quad(5 \mathrm{~b}) \\
C=C^{\prime \prime} & \text { at } x=L_{1}+L(5 \mathrm{c}) \\
\varepsilon_{\mathrm{b}} D_{\mathrm{ax}} \frac{\partial C}{\partial x}=D^{*} \frac{\partial C^{\prime \prime}}{\partial x} & \text { at } x=L_{1}+L(5 \mathrm{~d})
\end{array}
$$

流動層上部の空管は十分に長く, 半無限長と近似する. トレーサが十分に低濃度であればヘンリー型の吸着平衡 を仮定して

$c_{\mathrm{ad}}=K_{\mathrm{A}} c$

Eqs. (1)〜 (6) をラプラス域で解けば, $x=L_{1}+L+L_{2}$ での 
濃度応答 $C^{\mathbb{I}}(t)$ についての伝達関数は

$$
\begin{gathered}
F(s)=\frac{\int_{0}^{\infty} C^{\mathbb{I}}(t) e^{-s t} d t}{\int_{0}^{\infty} C^{\mathrm{I}}(t) e^{-s t} d t} \\
=\frac{\exp \left[\frac{u\left(L_{1}+L_{2}\right)}{2 D^{*}}\left(1-\sigma^{*}\right)+\frac{u L}{2 \varepsilon_{\mathrm{b}} D_{\mathrm{ax}}}(1-\sigma)\right]}{1+\frac{\sigma^{*}-\sigma}{2 \sigma}\left\{1-\frac{\sigma+\sigma^{*}}{2 \sigma^{*}}\left(1-\exp \left[-\frac{u L_{1}}{D^{*}} \sigma^{*}\right]\right)\right\}\left(1-\exp \left[-\frac{u L}{\varepsilon_{\mathrm{b}} D_{\mathrm{ax}}} \sigma\right]\right)}
\end{gathered}
$$

$$
\sigma=\sqrt{1+\frac{4 \varepsilon_{\mathrm{b}}^{2} D_{\mathrm{ax}}}{u^{2}}\left(s+\frac{D_{\mathrm{e}} a}{\varepsilon_{\mathrm{b}} R} \frac{1}{\frac{D_{\mathrm{e}}}{k_{\mathrm{f}} R}+\frac{1}{\phi \operatorname{coth} \phi-1}}\right)}
$$

$$
\begin{aligned}
& \sigma^{*}=\sqrt{1+\frac{4 D^{*} s}{u^{2}}} \\
& \phi=R \sqrt{\frac{s}{D_{\mathrm{e}}}\left(\varepsilon_{\mathrm{p}}+\rho_{\mathrm{p}} K_{\mathrm{A}}\right)}
\end{aligned}
$$

\section{$1 \cdot 1$ 空管の場合}

流動粒子がなく空管の場合には Eq. (1)が $x>0$ の全域 で成り立つ. たとえば $x=L_{1}+L+L_{2}$ での伝達関数は次 式で与えられる。

$$
F(s)=\exp \left[\frac{u\left(L_{1}+L+L_{2}\right)}{2 D^{*}}\left(1-\sigma^{*}\right)\right]
$$

\section{2 流動層の場合一濃度信号に含まれる雑音の除去 と応答濃度曲線の計算}

測定した濃度曲線には層内の圧力变動に伴うと考えら れる不規則信号（こてでは雑音と呼ぶ）が含まれている。 てれをつぎのようにして取り除く.

濃度信号が消滅するような十分長い時間を $2 \tau$ とし， 実測の曲線を時間 $0 \sim 2 \tau$ の区間で Fourier 級数に展開 する，たとえば，応答信号については

$$
C^{\mathbf{I}}(t)_{\operatorname{expt}}=\frac{a_{0}{ }^{*}}{2}+\sum_{n=1}^{\infty}\left(a_{n}{ }^{*} \cos \frac{n \pi t}{\tau}+b_{n}^{*} \sin \frac{n \pi t}{\tau}\right)
$$

ここで Fourier 係数は

$$
\begin{aligned}
& a_{n}{ }^{*}=\frac{1}{\tau} \int_{0}^{2 \tau} C^{\mathbb{I}}(t)_{\text {expt }} \cos \frac{n \pi t}{\tau} d t \\
& b_{n}^{*}=\frac{1}{\tau} \int_{0}^{2 \tau} C^{\mathbb{I}}(t)_{\text {expt }} \sin \frac{n \pi t}{\tau} d t
\end{aligned}
$$

濃度信号が低周波成分から構成されているのに対して, 雑音は比較的高い周波数から成っている. てのため濃度 信号之雑音とを周波数域で分離することができる. 実際 には，Eq. (10)の Fourier 級数を有限項 (N 項まで) で打 ち切ることで雑音を除去し濃度信号を平滑化する。

$$
C^{\mathrm{II}}(t)_{\mathrm{calc}}=\frac{a_{0}^{*}}{2}+\sum_{n=1}^{\mathrm{N}}\left(a_{n}^{*} \cos \frac{n \pi t}{\tau}+b_{n}^{*} \sin \frac{n \pi t}{\tau}\right)
$$

入口濃度信号 $C^{\mathrm{I}}(t)_{\text {expt }}$ もガス流速が大きくなると雑音 を含むが上記と同じ方法でその雑音の除去が可能である. さて, 入口の $C^{\mathrm{I}}(t)_{\text {expt }}$ 曲線と系の伝達関数を用い, 若 尾・影井 ${ }^{6)}$ の方法により出口の $C^{\mathbb{I}}(t)_{\text {calc }}$ と計算できる. てのとき伝達関数に含まれている未知の因子の值を仮定 するが，乙うして求めた $C^{\mathbb{I}}(t)_{\text {calc }}$ が $C^{\mathbb{I}}(t)_{\text {expt }}$ とよく一 致するならば，はじめに仮定した因子の值が正しいてと になる。

\section{2. 実験装置と方法}

実験装置の概略をFig. 1(a) 飞，流動層部分のやや詳 細をFig. 1 (b) 亿示す.内径 $39 \mathrm{~mm}$, 外径 $45 \mathrm{~mm}$ の透明 アクリル円管内に助走区間としての固定層（直径 $2.2 \mathrm{~mm}$ のガラスビーズ充填層）を設け，その上部に平均粒径 $0.3 \mathrm{~mm}$ のモレキュラーシーブ $5 \mathrm{~A}$ (Davison, 粒径 1 3 $\mathrm{mm}$ のものを破砕し, さらに JIS 42〜 60メッシュに篩分 したあの）からなる流動層をつくる。なお，モレキュラ ーシーブ $5 \mathrm{~A}$ 粒子は $300^{\circ} \mathrm{C}$ で 2 時間ヘリウム気流中で再 生したあのである. キャリアガスのへリウムは別に設け たモレキュラーシーブ $5 \mathrm{~A}$ カラムによって脱湿してのア クリル円管に供給する.流動層の支持板は厚さ $0.5 \mathrm{~mm}$ のアルミ板に直径 $0.5 \mathrm{~mm}$ のをピッチ $1 \mathrm{~mm}$ の正三角形 配列に多数穿ち, さらにこのアルミ板を布で覆ったもの である．乙の支持板と助走区間のガラスビーズ上端面と の間の距離は $60 \mathrm{~mm}$ で, 支持板の下 $15 \mathrm{~mm}$ の空管部中 央に 1 本のタングステン・フィラメントを挿入する。一 方, 流動層出口での濃度測定のために分散板の上 $230 \mathrm{~mm}$ の管中央部にあう 1 本のタングステン・フィラメントを 設置する。なお，本実験での流動層の層高は $75 \mathrm{~mm}$ 以下， 静止時充塤高さは $50 \mathrm{~mm}$ である。

パルス応答実験は，まずキャリアガスを所定の流量で 管内に流し，濃度測定用のフィラメントのブリッジ回路 のバランスをとる.フィラメントからの信号が安定して 得られるようになってから, ガラスビーズ固定層下部の トレーサ注入口より注射針で窒素ガスを $2 \sim 5 \mathrm{~m} l$ 注入し, 流動層の上下に設置した 2 本のフィラメントでトレーサ 濃度一時間曲線をそれぞれ測定する。系の温度は $20^{\circ} \mathrm{Cで}$ ある.また，支持板下部の管壁に設けた圧カタップによ り流動層の圧力損失を水柱マノメータで求める. キャリ アガスの流量は流動層出口に設けた積算流量計で測定す る.

なお，流動層の空隙率 $\varepsilon_{\mathrm{b}}$ は固定層高之流動層高の比 执よび固定層時の空隙率 (0.4) から求める. 層単位体積 


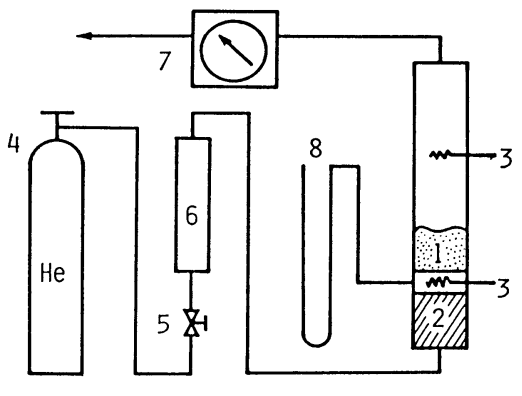
1. Fluidized bed
5. Valve
2. Calming section
6. Drying column
3. Tungsten filament
7. Gas meter
4. Helium cylinder
8. Manometer

(a)

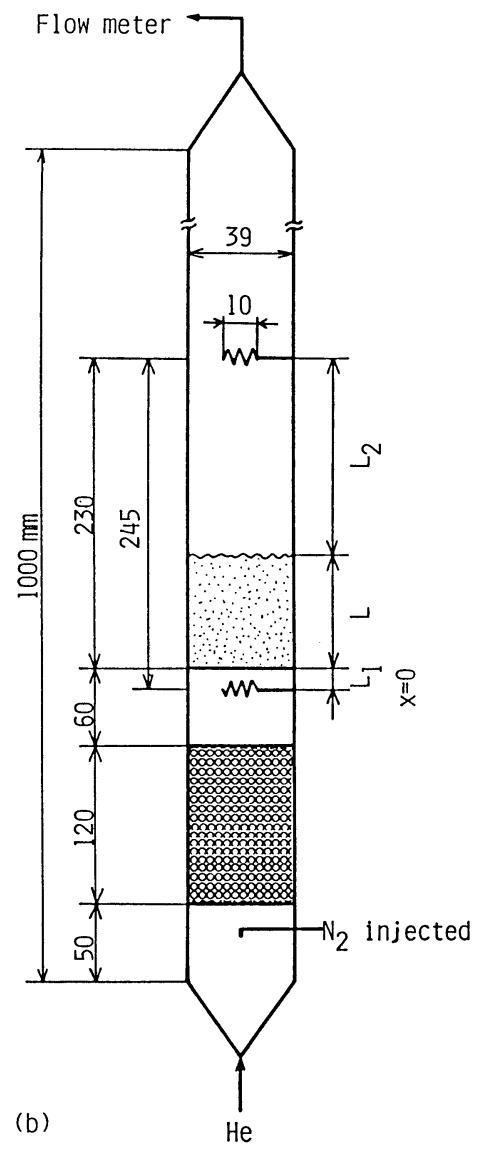

Fig. 1 Schematic of the apparatus. (a): The whole system; (b): Fluidization column

あたりの表面積 $a$ は次式による.

$$
a=\frac{3\left(1-\varepsilon_{\mathrm{b}}\right)}{R}
$$

また，乙の装置でモレキュラーシーブ粒子を投入せず，

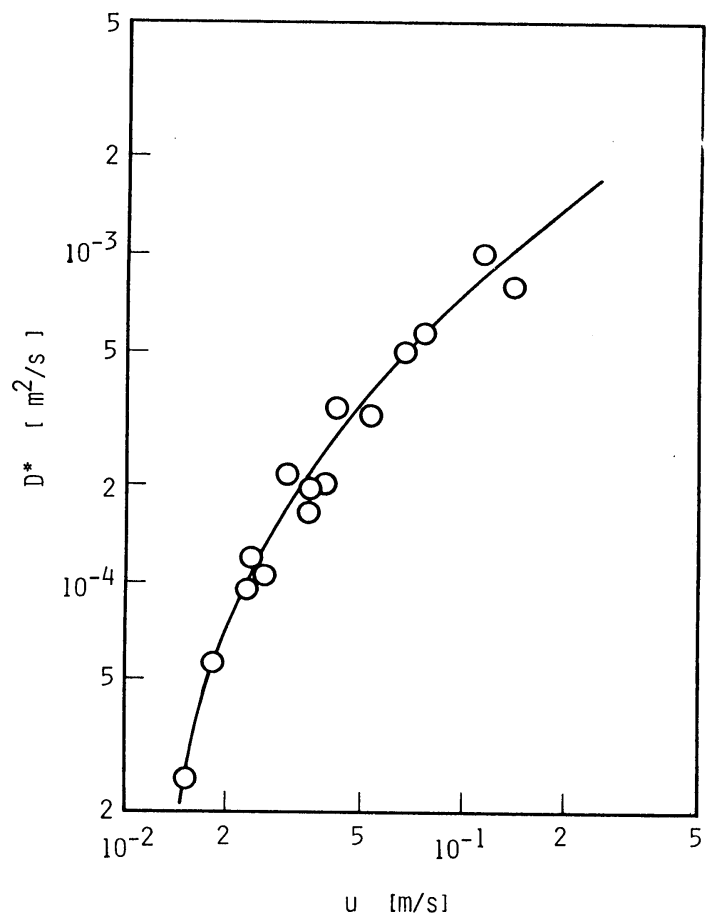

Fig. $2 D^{*}$ data for an empty column

支持板上を空管とした濃度応答実験も併せて行った。乙 れは，空管の場合についてのガス混合係数を求めるため である。

\section{3. 実験結果と考察}

\section{$3 \cdot 1$ 空管の場合}

伝達関数 Eq. (9) での未知因子は $D^{*}$ のみである. 種々 の $D^{*}$ 值を仮定して前述の方法により応答の濃度－時間 曲線を推算し, 実測デー夕之時間域で比較して, 最適の $D^{*}$ 值を見出す。乙うして求めた $D^{*}$ 值を流速 $u$ 亿対して 描くとFig. 2 亿示すようになる。

\section{$3 \cdot 2$ 濃度曲線の平滑化}

Figs. 3(a), 4(a) は測定した入口濃度曲線とその応答 曲線を示したあのである. 流動化は $u_{\mathrm{mf}}=0.057 \mathrm{~m} / \mathrm{s}$ で 起き，Fig. 3(a) は $u=0.068 \mathrm{~m} / \mathrm{s}\left(u / u_{\mathrm{mf}}=1.19\right)$ のバブリ ング状態, Fig. 4 (a) は $u=0.092 \mathrm{~m} / \mathrm{s}\left(u / u_{\mathrm{mf}}=1.61\right)$ で 流動化がさらに進んだ状態である。 バブリング時の入口 および応答濃度曲線は若干の変動分を含み, 流動化が進 むと変動分は大いに増大する. 乙の变動分は流動層支持 板上での気泡の発生，固体粒子層の運動と気泡の分散· 合一，層上端面での気泡の破裂消滅などに伴う層内の局 所的打よび層全体の圧力変動に多く起因すると考えられ る. このように，乙の変動分は流動状態や気泡の挙動に ついての情報を含むであろうが，濃度信号に関しては雑 
音と考え，てれを1.2で述べた方法で取り除いた。

Figs. 3 (a), 4 (a) 亿示した応答濃度曲線の周波数スぺ クトル分布をFigs. 3(b), 4(b) 亿示す. いずれの場合む, 振幅はある周波数で最大になったあとは周波数が増える ととあに減少するが, 約 $0.2 \mathrm{~Hz}$ 以上では振幅は凹凸状態 となる．稳やかな流動状態 Fig. 3(b) ではこの凹凸信, 号 も周波数が増えるとともに減少するが，流動状態が進ん だFig. 4(b) では周波数が高くなっても凹凸状態がその まま継続する．いずれの場合す $0.2 \mathrm{~Hz}$ 以上の周波数部分 を雑音と見なして除去すると応答濃度曲線はFigs. 3(c), 4 (c) のように平滑化される。なお，流動化が進んだ場合 には入口濃度一時間曲線にも雑音信号が増える, 応答濃 度曲線之は異なり, 入口濃度曲線自体にはやや高周波成 分（約 $2 \mathrm{~Hz}$ まで）を含んでいるので, こてでは $2 \mathrm{~Hz}$ 以上 を雑音として除去した。なお，応答濃度曲線の計算には $0.2 \sim 2 \mathrm{~Hz}$ までの周波数成分は全く影響を与えていない. Fig. 4 (c) にはてのようにして平滑化された入口濃度曲線 をも示した。

\section{3 流動状態での吸着平衡定数とガス混合係数の推}

モレキュラーシーブ粒子を投入した場合にはこの流動 層の末知因子はガス混合係数 $D_{\mathrm{ax}}$ とモレキュラーシーブ 粒子の吸着平衡定数 $K_{\mathrm{A}}$, 粒内有効拡散係数 $D_{\mathrm{e}}$ および粒 子一流体間の物質移動係数 $k_{\mathrm{f}}$ である。なお，モレキュラ ーシーブ $5 \mathrm{~A}$ の粒子密度, 粒内空隙率, $\mathrm{He}-\mathrm{N}_{2}$ 系での $\mathrm{N}_{2}$ ガスの粒内有効拡散係数はLee ら ${ }^{3)}$ により $\rho_{\mathrm{p}}=1210 \mathrm{~kg} /$ $\mathrm{m}^{3}, \varepsilon_{\mathrm{p}}=0.51, D_{\mathrm{e}}=7.5 \times 10^{-7} \mathrm{~m}^{2} / \mathrm{s}$ 之求められている. また， $k_{\mathrm{f}}$ の值は固定層吸着に打いては非常に大きく，し たがって境膜拡散抵抗はほとんど無視少であるてとが知 られている7). 初期流動層に扔いての $k_{\mathrm{f}}$ の值は固定層と 同程度またはさらに大きいと考えられるので，乙てでは $k_{\mathrm{f}}=\infty$ を仮定した。流動層上下の空管部分の $D^{*}$ 值はFig. 2 の実線からその流速に対応する值を読み取って計算に 用いた.

すなわち，未知因子は $D_{\mathrm{ax}}$ と $K_{\mathrm{A}}$ であり，乙れらの值 を種々仮定して, 前述の方法により $C^{\mathbb{I}}(t)_{\text {calc }}$ を求め, 次 式で $C^{\mathbb{I}}(t)_{\text {expt }}$ との間の平均自乗誤差を求めた。（参考文 献 ${ }^{6)}$ )

$$
\varepsilon=\left[\frac{\int_{0}^{\infty}\left\{C^{\mathbf{I}}(t)_{\text {expt }}-C^{\mathbf{I}}(t)_{\text {calc }}\right\}^{2} d t}{\int_{0}^{\infty}\left\{C^{\mathbb{I}}(t)_{\text {expt }}\right\}^{2} d t}\right]^{1 / 2}
$$

なお, Fig. 4(a) 亿示すように, 入口濃度曲線の雑音信号 が大きい場合には Fig. 4(c)のように入口濃度曲線も平 滑化して, $C^{\mathbf{I}}(t)_{\text {calc }}$ の計算に用いた。

Fig. 3(a) に示す $u=0.068 \mathrm{~m} / \mathrm{s}$ の場合, 上記のように して求めた $\varepsilon$ を誤差等高線で描いたのが Fig. 3(d) であ
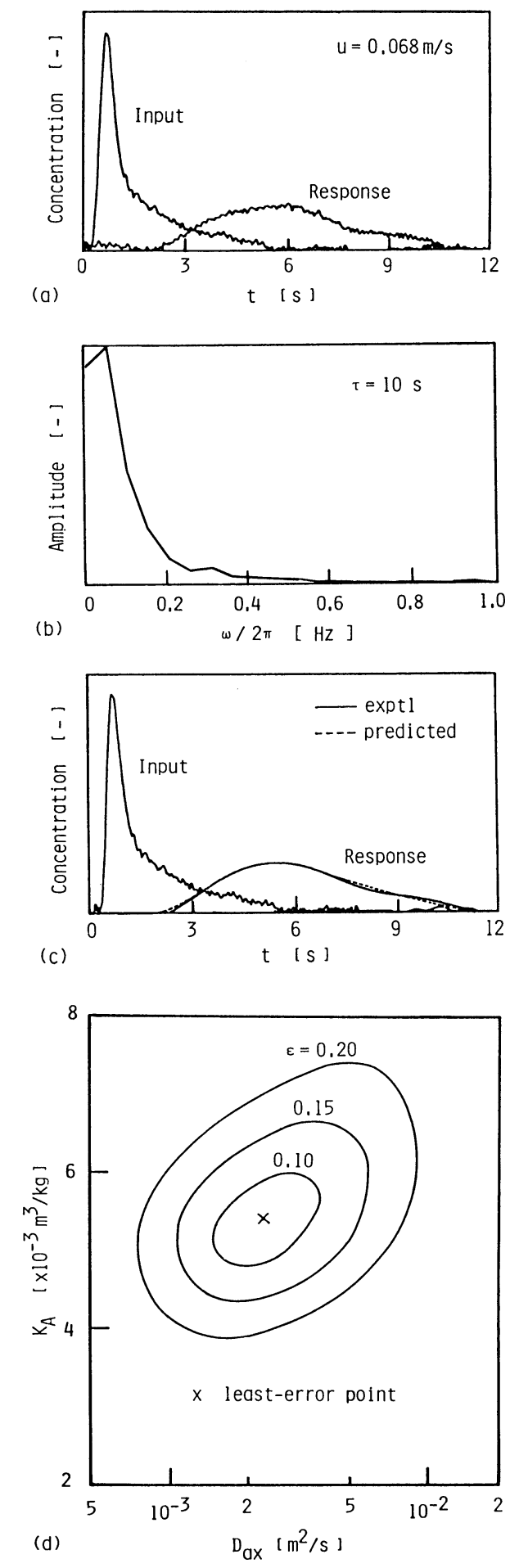

Fig. 3 Moderate fluidization at $u=0.068 \mathrm{~m} / \mathrm{s}$.

(a) : Input and response signals measured;

(b) : Spectra of the response signal measured;

(c): Smoothed response signal, compared with the best-fit response signal predicted; (d): Frror map in the plot of $K_{\mathrm{A}}$ vs. $D_{\mathrm{ax}}$ 

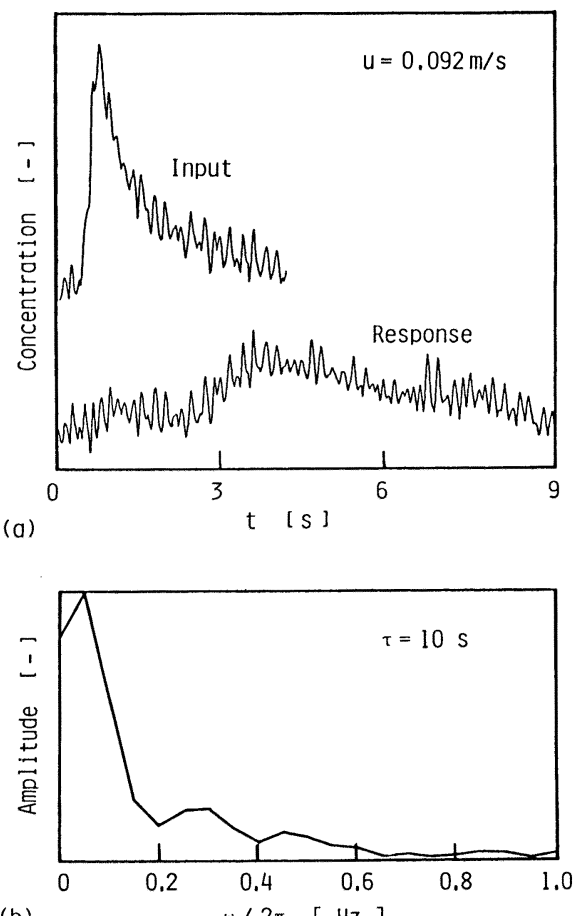

(b)

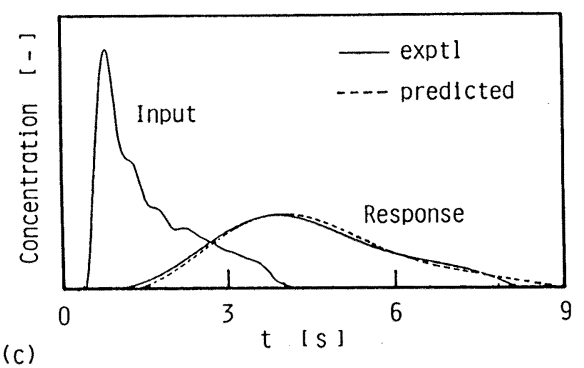

(c)

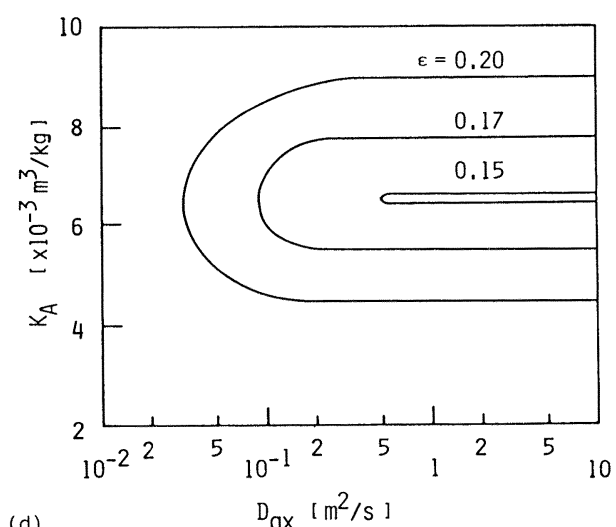

Fig. 4 Fluidization at $u=0.092 \mathrm{~m} / \mathrm{s}$. (a) : Input and response signals measured; (b): Spectra of the response signal measured; (c): Smoothed input and response signals, compared with the best -fit response signal predicted; (d): Error map in the plot of $K_{\mathrm{A}}$ vs. $D_{\mathrm{ax}}$
る.たとえば, $\varepsilon=0.1$ の線で四まれた域内の $K_{\mathrm{A}}$ 值と $D_{\mathrm{ax}}$ 值を用いて $C^{\mathbb{I}}(t)_{\text {calc }}$ を求めた場合, 実測曲線との誤差 が $\varepsilon<0.1$ であるてとを示している．乙の域内の最小誤 差点 $(\varepsilon=0.073)$ より $K_{\mathrm{A}}=5.4 \times 10^{-3} \mathrm{~m}^{3} / \mathrm{kg}, D_{\mathrm{ax}}=2.4 \times$ $10^{-3} \mathrm{~m}^{2} / \mathrm{s}$ が求まる。なお, Fig. $3(\mathrm{c})$ 亿実測の入口濃度 曲線 $C^{\mathrm{I}}(t)_{\text {expt }}$ 之最小誤差点の $K_{\mathrm{A}}, D_{\mathrm{ax}}$ の值を用いて計算 した応答濃度曲線 $C^{\mathbb{I}}(t)_{\text {calc }}$ を点線で, 実測の応答濃度曲 線 $C^{\mathbb{I}}(t)_{\text {expt }}$ を実線で示したが, よい一致を示している.

一方，流速の大きな場合の誤差面はFig. 4(d) 亿示す ように, $D_{\mathrm{ax}}$ の感度が鈍く, 応答実験からの $D_{\mathrm{ax}}$ 值の算 出は困難になる。なお， Fig. 4 (c) 亿平滑化した入口濃度 曲線と $K_{\mathrm{A}}=6.5 \times 10^{-3} \mathrm{~m}^{3} / \mathrm{kg}, D_{\mathrm{ax}}>0.5 \mathrm{~m}^{2} / \mathrm{s}$ の値を用い て計算した応答濃度曲線を点線で示した。 乙の場合も実 線で示した実測曲線とよく一致している.

つぎに，乙うして求めた $K_{\mathrm{A}}$ 抢よび $D_{\mathrm{ax}}$ の值と流速の 関係をみる. 吸着平衡定数は流速依存せずに一定のは ずで，事実Fig. 5 では $K_{\mathrm{A}}$ が $u$ 亿無関係に約 $6 \times 10^{-3} \mathrm{~m}^{3}$ / kg であることがわかる. 一方, Fig. 6 は $u$ が増えると ともに $D_{\mathrm{ax}}$ が急激に増加することを示している.

固定層の流体混合（拡散）係数についての多くの実験 結果をまとめると ${ }^{6)} \operatorname{Re}<1$ では $D_{\mathrm{ax}}=(0.6 \sim 0.8) D_{\mathrm{v}}$ であ る. Fig. 6 ではての事実を参考にして $u$ の小さな域での 線を画いてある。なお， $\mathrm{D}_{\mathrm{v}}$ は分子拡散係数で， $20^{\circ} \mathrm{C}$ で の $\mathrm{He}-\mathrm{N}_{2}$ 系では $D_{\mathrm{v}}=0.705 \times 10^{-4} \mathrm{~m}^{2} / \mathrm{s}$ である. 本実験で 流動化開始流速時のレイノルズ数は $(\mathrm{Re}) \mathrm{min}=0.15$ であ る.したがって, 流動化開始までは $D_{\mathrm{ax}}=(0.6 \sim 0.8) \times$ $0.705 \times 10^{-4}=(0.42 \sim 0.56) \times 10^{-4} \mathrm{~m}^{2} / \mathrm{s}$ と考えられ，流 動化を開始すると $D_{\mathrm{ax}}$ は急激に大きくなるととがわかる. 宮内 ${ }^{4)}$ は気固系流動層で $D_{\mathrm{ax}}$ は $u$ 亿比例し, $D_{\mathrm{ax}} / u$ が 流動層の管径のみの関数としているが, 本実験から求ま った $D_{\mathrm{ax}}$ は宮内らの整理式より遥玑大きく，また，流 速への依存度も大である.

な扔，本研究では $D_{\mathrm{e}}$ 值を文献 ${ }^{3)}$ から $D_{\mathrm{e}} / D_{\mathrm{v}}=0.01$ 乙 て $K_{\mathrm{A}}$ 値と $D_{\mathrm{ax}}$ 值を求めたが, 応答曲線の計算で $K_{\mathrm{A}}$ や $D_{\mathrm{ax}}$ に比して $D_{\mathrm{e}}$ の寄与は少なく, 仮に $D_{\mathrm{e}} / D_{\mathrm{v}}=0.005$ 0.1 としても計算応答曲線にほとんど差異が無いととが 確認されている.

本研究では応答濃度曲線や入口濃度曲線から雑音を除 き, 濃度一時間曲線を平滑化することで流動層内のガス 混合係数と吸着平衡定数を求めた。入口濃度に対する応 答濃度曲線の遅れと鈍化は流動層内のガス混合と吸着に よるためであり, 吸着平衡定数の算出值がガス流速に依 存しなかったてとから, 本研究で用いたモデルが妥当で あったと考えられる．乙のモデルにより，固定層および $u / u_{\mathrm{mf}}<1.2$ の初期流動化の範囲で $D_{\mathrm{ax}}$ 值と $K_{\mathrm{A}}$ 值 の両 者の同時算出が可能であった。 


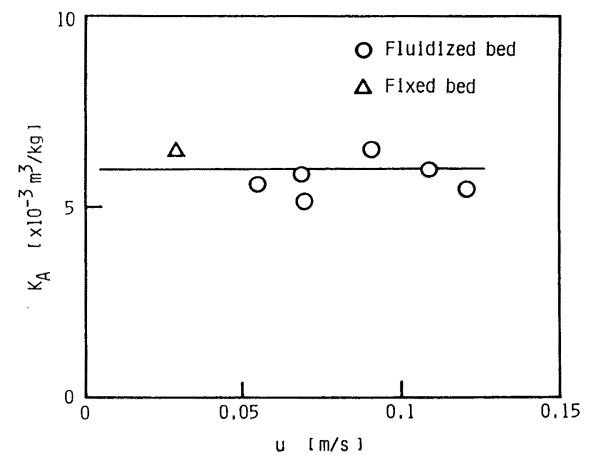

Fig. $5 K_{\mathrm{A}}$ vs. $u$

\section{結言}

モレキュラーシーブ $5 \mathrm{~A}$ の破砕微粒子流動層にへリウ ムをキャリアガスとして流し，てれに $\mathrm{N}_{2}$ ガスを任意波 形でパルス入力し，その入口濃度曲線および応答濃度曲 線を測定した。

流動化が進むと入口濃度曲線, 応答濃度曲線ともに流 動層の压力変動に基づくと考えられる激しい変動分を持 つととがわかったが，周波数解析を行い，比較的高い周 波数成分を除去することで平滑化された濃度曲線を得る ことができた。乙の平滑濃度曲線を用い流動層内のガス 混合係数之吸着平衡定数を求めた。吸着平衡定数はその 物理的意味の通りガス流速には無関係に一定値を示し， ガス混合係数はガス流速が増えるとともに著しく増加す るととが認められた。なお，流速が大きな場合，平滑化 による雑音の除去は可能であるが $D_{\mathrm{ax}}$ の感度は鈍くなり 濃度応答曲線から $D_{\mathrm{ax}}$ 值を求めることは困難であった。 吸着平衡定数とガス混合係数の同時算出は $u / u_{\mathrm{mf}}<1.2$ の初期流動化の域で可能であった。

\section{Nomenclature}

$a=$ particle surface area per unit bed volume

$\left[\mathrm{m}^{2} / \mathrm{m}^{3}\right]$

$C=$ bulk gas concentration ( $C$ ' and $C$ " for empty sections, and $C$ for fluidized bed )

$\left[\mathrm{kg} / \mathrm{m}^{3}\right]$

$c=$ gas concentration in pore

$c_{\mathrm{ad}}=$ amount adsorbed per unit mass of adsorbent

$D_{\text {ax }}=$ gas mixing coefficient in fluidized bed

$\left[\mathrm{kg} / \mathrm{m}^{3}\right]$

intraparticle effective diffusivity

$\left[\mathrm{m}^{2} / \mathrm{s}\right]$

$\left[\mathrm{m}^{2} / \mathrm{s}\right]$

$D_{\mathrm{v}}=$ molecular diffusivity (between $\mathrm{He}$ and

$\mathrm{N}_{2}$ )

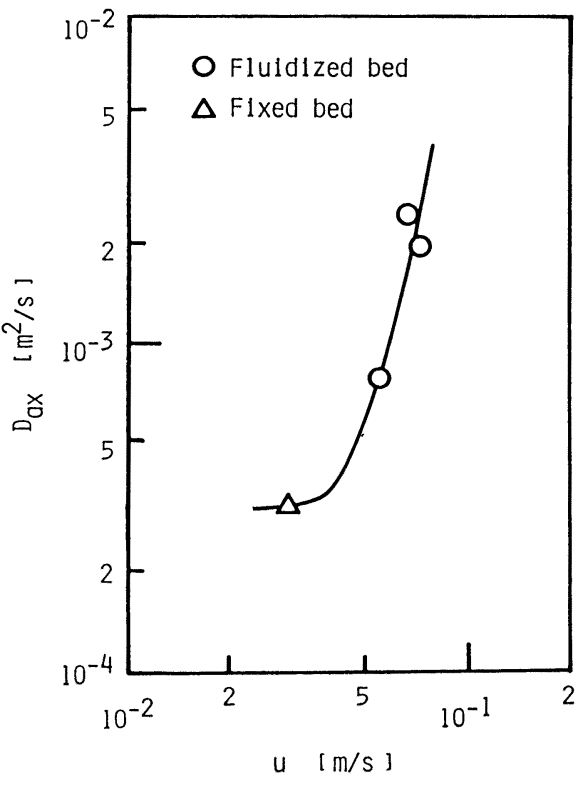

Fig. $6 \cdot D_{\text {ax }}$ vs. $u$

$D^{*}$ = gas mixing coefficient in empty section $\left[\mathrm{m}^{2} / \mathrm{s}\right]$

$F(s)=$ transfer function

$K_{\mathrm{A}}=$ adsorption equilibrium constant $\quad\left[\mathrm{m}^{3} / \mathrm{kg}\right]$

$k_{\mathrm{f}}=$ particle-gas mass transfer coefficient $[\mathrm{m} / \mathrm{s}]$

$L=$ height of fluidized bed [m]

$R=$ particle radius

$\operatorname{Re}=2 R u \rho_{\mathrm{F}} / \mu$, Reynolds number

$r$ = radial distance variable in a particle

$t=$ time

$u=$ superficial gas velocity

$u_{\mathrm{mf}}=$ minimum fluidization velocity

$x=$ axial distance variable

$\varepsilon=$ root-mean-square error defined by

Eq. (13)

$\varepsilon_{\mathrm{b}}=$ extraparticle void fraction

$\varepsilon_{\mathrm{p}}=$ intraparticle void fraction

$\mu=$ gas viscosity

$\rho_{\mathrm{F}}=$ gas density

$\rho_{\mathrm{p}}=$ particle density

$\tau=$ half of a time which is long enough to let the tail of response signal vanish $\omega=$ angular frequency $[\mathrm{rad} / \mathrm{s}]$ $<$ Superscripts $>$

I = input

II $=$ response 


\section{Literature cited}

1) Gilliland, E.R. and E.A. Mason: Ind. Eng. Chem., 44, 218 (1952)

2) Gunn, D.J. and P.V. Narayanan: Chem. Eng. Sci., 36, 1985 (1981)

3) Lee, D.I., S. Kaguei and N. Wakao: J. Chem. Eng. Japan, 14, 161 (1981)
4) Miyauchi, T., H. Kaji and K. Saito: J. Chem. Eng. Japan, 1, 72 (1968)

5) Miyauchi, T., S. Furusaki, S. Morooka and Y. Ikeda: Adv. Chem. Eng., 11, 374 (1981)

6) Wakao, N. and S. Kaguei: Heat and Mass Transfer in Packed Beds, Gordon-Breach, New York(1982)

7) Wakao, N., S. Kaguei and J.M. Smith: Ind. Eng. Chem. Fundam., 19, 363 (1980)

\title{
Estimation of Parameters in a Gas-Solid Fluidized- Bed Adsorber by the Concentration Response Technique - At incipient fluidization-
}

\author{
Masahiro Nishio, Seiichiro Kaguei and Noriaki Wakao \\ Faculty of Engineering, Yokohama National University, Yokohama 240
}

Key Words : Fluidized Bed, Adsorption, Input-Response Technique, Gas Mixing

Coefficient, Adsorption Equilibrium Constant, Parameter Estimation

Nitrogen gas was introduced as a shot tracer into a column far below a bed of finely ground molecular sieve $5 \mathrm{~A}$ particles fluidized with helium gas. Inlet and response nitrogen concentration-time curves measured respectively below and above the fluidized bed were found to have considerable noise. Using smoothed input and response curves obtained by eliminating the noise, values of gas mixing coefficient and adsorption equilibrium constant were estimated in the range up to the nearincipient fluidization stage. 